\title{
Special School as One of the Implementers of Education for Sustainable Development of Persons with Moderate and Severe Intellectual Disability, as well as Multiple Disability
}

\begin{abstract}
Iwona Wendreńska, Special school as one of the implementers of education for sustainable development of persons with moderate and severe intellec-tual disability, as well as multiple disability. Interdisciplinary Contexts of Special Pedagogy, no. 27, Poznań 2019. Pp. 163-180. Adam Mickiewicz University Press. ISSN 2300-391X. e-ISSN 2658-283X. DOI: https://doi.org/10.14746/ikps.2019.27.08

The basis for choosing the subject of this article was the conviction that due to the recent expansion of the meaning of the term "sustainable development", the essence of education for sustainable development, its objectives and tasks implemented in different types of schools, including special schools, are also subject to change. The article will present the results of research covering, on the one hand, the analysis of strategic and programme documents and, on the other hand, the results of surveys conducted among 164 teachers employed in special education institutions in the Silesian and Lublin Voivodships.
\end{abstract}

KEY WORDS: education for sustainable development, special school, core curriculum 


\section{Introduction}

The basic tasks of a modern special school include equipping students with key competences, understood as a combination of knowledge, skills and attitudes necessary for personal development and self-fulfilment, building civil society, social integration and employment. One of these competences, which is an important condition for achieving the others, is the ability to learn. As Józef Bałachowicz rightly pointed out ${ }^{1}$, taking into account the new categories appearing in international reports on learning as one of the key competences of modern man, the following paradigms (education pillars) can be identified: 1) to learn to know; 2) to learn to act; 3) to learn to live together; 4) to learn to be; 5) to learn to be innovative; 6) to learn to live in a sustainable way².

If one of the paradigms is to prepare individuals and groups to live in a sustainable way, then the question arises: What does it mean to live in a sustainable way? On the face of it, the answer to this question seems simple. It is contained in the statement: respecting, implementing the idea of sustainable development at the individual and social level. It should be remembered, however, that sustainable development is defined in different ways ${ }^{3}$, as referred to later in this article.

\section{From the idea of sustainable development to education for sustainable development}

The term sustainable development was introduced in the 19th century by Hans Carl von Carlowitz to describe forest management

${ }^{1}$ J. Bałachowicz, Idea zrównoważonego rozwoju w edukacji dziecka, "Prima Educatione" 2017, Vol. 1, p. 29.

2 Previously, this pillar of education was defined as: Learning to transform oneself and society.

${ }^{3}$ Z. Bukowski, Zrównoważony rozwój w systemie prawa, Towarzystwo Naukowe Organizacji i Kierownictwa, Torun 2009, p. 26. 
in which only as many trees can be felled, as many can grow in their place $^{4}$. In the 1970s, it appeared in international documents ${ }^{5}$. And from that time it became one of the priorities of the present and future generations ${ }^{6}$. Sustainable development was then defined as "such a course of inevitable economic development that would not significantly and irreversibly harm the environment of human life, would not lead to the degradation of the biosphere, not violate the laws of nature, economics and culture" 7 . Originally, sustainable development was interpreted primarily in terms of environmental sustainability. This approach can also be found in contemporary studies $^{8}$. Over time, however, it was noticed that it is impossible to effectively protect the environment without respecting the rights of local communities, democratic principles and participation in building civil society, efforts to eliminate poverty and hunger and develop entrepreneurship. This concept, therefore, assumes a balance

${ }^{4}$ Cf. L. Pawłowski, Rola monitoringu środowiska w realizacji zrównoważonego rozwoju, „Rocznik Ochrona Środowiska” 2011, Vol. 13, p. 334.

5 The term sustainable development was first used in the Declaration of the Stockholm Conference in 1972. Its definition was proposed at the second session of the United Nations Environment Programme (UNEP) Governing Council in 1975. The report of the World Commission on Environment and Development entitled Our Common Future from 1987 (Nasza wspólna przyszłość. Raport Światowej Komisji do Spraw Środowiska i Rozwoju, PWN, Warszawa 1991), also known as the Brundtland Commission Report, contributed to its popularization (for more details see: A. Papuziński, Edukacja ekologiczna jako instrument polityki ekologicznej, [in:] Polityka ekologiczna III Rzeczypospolitej, ed. A. Papuziński, Wydawnictwo Uczelniane AB, Bydgoszcz 2000, p. 115).

${ }^{6}$ Cf. e. g. the Treaty on the European Union signed in Maastricht in 1992 and its amending Treaty of Amsterdam signed in 1997, <www.europarl.europa.eu/fact sheets/pl/sheet/3/traktat-z-maastricht-i-traktat-z-amsterdamu> [30 IV 2019].

${ }^{7}$ Quote after: Z. Kozak, O pojęciach rozwoju zrównoważonego i ekorozwoju, [in:] Ochrona środowiska w filozofii i teologii, ed. J.M. Dołęga, J.W. Czartoszewski, Wydawnictwo ATK, Warszawa 1999, p. 257.

8 The National Strategy for Ecological Education, Ministry of the Environment, Warszawa 2001, p. 5; B. Banaszak, The Constitution of the Republic of Poland, C.H. Beck, Warszawa 2012, p. 74; A. Walosik, Przez edukację do zrównoważonego rozwoju, Wydawnictwo Naukowe UP, Kraków 2013, p. 5 et seq. 
between economic, social, political and ecological aspects, which is a condition for maintaining a high quality of life not only for contemporary people, but also for future generations ${ }^{9}$. The holistic approach to sustainable development was evident, inter alia, at the UN Millennium Summit (2000) ${ }^{10}$, the World Summit on Sustainable Development $(\mathrm{RIO}+10)$ in Johannesburg (2002), the World Summit on Sustainable Development RIO+20 in Rio de Janeiro (2012) ${ }^{11}$ and the 70th Session of the United Nations General Assembly in New York $(2015)^{12}$. An important feature of the concept of sustainable development is that it does not describe a particular state of affairs, but is rather of a postulative nature ${ }^{13}$, sets the course for change. The understanding of sustainable development adopted in this article is presented in the following diagram.

A necessary condition for the implementation of this model is to undertake intentional, systemic, multidimensional actions within the framework of education for sustainable development (ESD). Its

${ }^{9}$ Cf. United Nations Educational, Scientific and Cultural Organization, Teaching and Learning for Sustainable Future, <http:/ / www.unesco.org./eduacation/tlsf/> [30.04.2019], E.M. Jastrzębska et al., Jak uczyć o społecznej odpowiedzialności i zrównoważonym rozwoju. Przewodnik dla nauczycieli, Forum Odpowiedzialnego Rozwoju, Warszawa 2011, p. 11, E. Lewandowska, Zrównoważony rozwój i edukacja dla zrównoważonego rozwoju. Konceptualizacja idei, [in:] Edukacja dla zrównoważonego rozwoju w perspektywie społeczeństwa wiedzy, ed. A. Korwin-Szymanowska, E. Lewandowska, A. Witkowska-Tomaszewska, Wydawnictwo Akademii Pedagogiki Specjalnej, Warszawa 2016, p. 42; P. Rydzewski, Social Dimensions of Sustainable Development in International Public Opinion, „Problemy Ekorozwoju - Problems of Sustainable Development" 2019, Vol. 14, No. 1, p. 53 et seq.

${ }^{10}$ Polish UNESCO Committee, UNESCO and the Decade of Education for Sustainable Development, <http://www.unesco.pl/edukacja/dekada-edukacji-nt-zrow nowazonego-rozwoju/unesco-a-zrownowazony-rozwoj> [30.04.2019].

11 E. Olejarczyk, Zasada zrównoważonego rozwoju w systemie prawa polskiego - wybrane zagadnienia, „Przegląd Prawa Ochrony Środowiska” 2016, No. 2, p. 124.

12 Polish UNESCO Committee, Agenda for Sustainable Development 2030, <http:/ / www.unesco.pl/662> [30.04.2019].

${ }_{13}$ Cf. B. Ogrodnik, Filozoficzne podstawy edukacji na rzecz zrównoważonego rozwoju, [in:] Filozofia, psychologia i ekologia w edukacji dla zrównoważonego rozwoju, ed. B. Ogrodnik, R. Kulik, P. Skubała, Śląski Ogród Botaniczny, Mikołów 2010, pp. 13-14. 


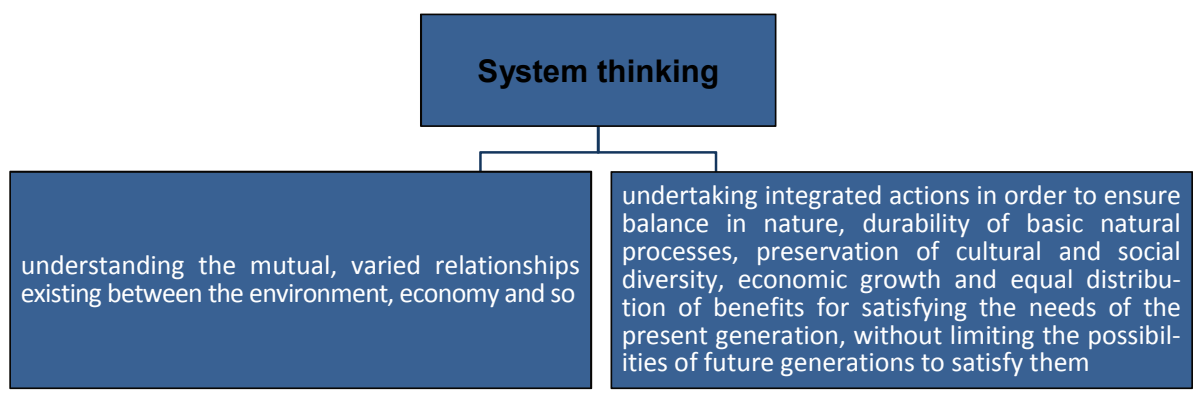

Fig. 1. Sustainable development model ${ }^{14}$

assumptions were presented, inter alia, in the report of the International Commission for Education for the 21st century entitled " $E d u$ cation. There is a hidden treasure in $i t^{\prime \prime} 15$. In Polish literature we can also find attempts to define what ESD is and what constitutes its essence. According to Joanna Kostecka, it should: enable prediction and solving of problems threatening life on Earth, serve the dissemination of values and principles conditioning sustainable development (gender equality, reduction of poverty areas, environmental protection, including the protection of the planet's natural resources, peaceful functioning of societies based on tolerance and justice), show the complexity and mutual interpenetration of three spheres: environment, society (including culture) and economy ${ }^{16}$.

14 Own study based on: J. Bałachowicz, Idea zrównoważonego..., op. cit., p. 24; A. Skowroński, Zrównoważony rozwój perspektywa dalszego postępu cywilizacyjnego, „Problemy Ekorozwoju - Problems of Sustainable Development” 2006, Vol. 1, No. 2, pp. 50-51; W. Sztumski, Idea zrównoważonego rozwoju a możliwości jej urzeczywistniania, "Problemy Ekorozwoju - Problems of Sustainable Development” 2006, Vol. 1, No. 2, pp. 73-74; M.K. Terlecka, Idea zrównoważonego rozwoju - o genezie, definicji, celach i zasadach słów kilka, [in:] Zrównoważony rozwój. Idea czy konieczność? Vol. 1, ed. A. Kleśta, M.K. Terlecka, Wydawnictwo ARMAGRAF, Krosno 2014, p. 9 et seq.

${ }^{15}$ Education - there is a treasure hidden in it. Report for UNESCO by the International Commission for Education chaired by Jacques Delors, Association of Polish Educators of the UNESCO Publishing House, Warszawa 1998.

16 Cf. J. Kostecka, Dekada edukacji dla zrównoważonego rozwoju - wizja, cel, strategia, „Problemy Ekorozwoju - Problems of Sustainable Development” 2009, vol. 4, No. 2, p. 102. 
It should not therefore be limited to the implementation of sustainable development content, but should also cover issues such as respect for human dignity, the rights of representatives of different communities, democratic principles and responsible participation in the development of a civil society that functions harmoniously at all levels, in particular cultural, economic, natural and social, and which meets its own needs, taking into account the needs of future generations ${ }^{17}$. Education for sustainable development requires an interdisciplinary approach to the education reform, offering all people, in all educational contexts and at all stages of life, the opportunity to learn a lifestyle that ensures their sustainable development. It goes far beyond formal education systems, but should have an impact on them, reflected in textbooks, curricula and teaching methods.

It is not easy to achieve these goals. In the past, it has generally taken the form of narrow, bottom-up, action-oriented activities ${ }^{18}$. The UN therefore established the years 2005-2014 as the Decade of Education for Sustainable Development, later also known as the Decade of Change. The primary tasks during this period were: promoting sustainable behaviour, inspiring critical and creative thinking to find solutions to problems that prevent sustainable development. The coordination of activities was entrusted to UNESCO. This UN agenda provided for the task of integrating the issues of sustainable development into the national educational systems and educational policies of the countries and raising awareness of the importance of the assumptions of sustainable development among various civil society entities, i.e. the media, social and non-governmental organizations, and the private sector. Our country also began to implement the principles of ESD. This process

17 For more details see e. g. K. Śledzińska, Kategoria odpowiedzialnego uczestnictwa jako aspekt edukacji na rzecz zrównoważonego rozwoju, [in:] Społeczna odpowiedzialność jako podstawa osiagania zrównoważonego rozwoju, ed. O. Kotowska-Wójcik, M. Luty-Michalak, Wydawnictwo Naukowe UKSW, Warszawa 2016, p. 86 et seq.

18 J. Bałachowicz, Idea zrównoważonego..., op. cit., p. 29. 
is being implemented by various entities, but as the Expert Report ${ }^{19}$ from 2012 has shown there was a lack of a single formalised network of cooperation, which was undoubtedly a major impediment. The study also pointed to the need to update the strategic document in force at that time, to clarify the understanding of sustainable development, to enable teachers to improve their professional skills, to create cooperation networks and to exchange experiences. On the other hand, the research undertaken by Ewa Gajuś-Lankamer and Anna Maria Wójcik, and later by Alicja Walosik and Anna Batorczak, shows that there exist formal and financial bases for implementing Education for Sustainable Development in Poland on a continuous basis. In the opinion of the authors, the content of the core curriculum makes it possible to conduct ESD at various educational stages, but most of the issues in this area are discussed within natural science classes. Moreover, the implementation of these contents is not of a systemic character, it is not always a priority, it is rarely checked within the framework of examination texts and constitutes only one of many areas of school work evaluation ${ }^{20}$.

The studies mentioned above consisted of a general evaluation of the implementation of education for sustainable development and lacked detailed information on special education institutions. And yet, modern special schools, which are moving away from complete segregation towards partial segregation ${ }^{21}$, have become

${ }^{19}$ Expert opinion on education for sustainable development in Poland. Final report. Developed by a team of ITTI consultants, commissioned by the Ministry of the Environment Poznań 2012, p. 3 et seq., <https:/ / www.gov.pl/web/srodowisko/ba dania-dotyczace-edukacji-dla-zrownowazonego-rozwoju> [30.04.2019].

${ }^{20}$ E. Gajuś-Lankamer, A.M. Wójcik, Analiza ciąłłości edukacji dla zrównoważonego rozwoju w aspekcie środowiskowym na różnych poziomach kształcenia ogólnego w Polsce, „Problemy Ekologii” 2009, Vol. 13, No. 5, pp. 249-250; A. Batorczak, Edukacja dla Zrównoważonego Rozwoju w Polsce i w Wielkiej Brytanii. doctoral dissertation, Warsaw University, Warszawa 2013, pp. 113-184, <https://depotuw.ceon.pl/bitstream/han dle/item/457/Praca\%20doktorska.pdf?sequence=1> [30.04.2019]; A. Walosik, Przez edukację do zrównoważonego..., op. cit., pp. 133-143.

${ }^{21}$ In the past, teachers of a special school were specialists in working with pupils with a given type of disability, today such schools are usually attended by peo- 
educational institutions for students with different special educational needs, and thus an environment in which they can encounter diversity, learn the principles of democracy, and develop tolerance for others. Teachers employed in special schools, thanks to changes in the core curriculum, EU projects and the resulting opportunities for cooperation and exchange of experiences with the staff of partner schools, gain new experiences useful in the process of instilling values and building competences of students, without which sustainable development would not be possible. With this in mind, the author of this article has undertaken pilot studies on the implementation of the principles of ESD in special education institutions.

\section{Assumptions and organization of own research}

Within the framework of the undertaken research procedure, answers to the following research questions were sought:

- What is the interpretation of the implementation of education for sustainable development in special education?

- What are the opinions of the surveyed teachers on the implementation of education for sustainable development in special schools?

- How do respondents assess the effects of the implemented measures?

The research included two stages. The first one consisted in the analysis of provisions in legislative and strategic documents, as well as in organizational and program documents of the examined institutions concerning the implementation of the sustainable development model, including ESD. In the second stage, a survey was conducted among special educators. Participation in the survey was offered to 200 teachers employed in special schools in the Silesian

ple with sensory disabilities, intellectual disabilities (moderate and severe), people with autism spectrum disorders, as well as people with multiple disabilities. Often, in special schools there are also revalidation and upbringing units for people with profound intellectual disabilities. 
and Lublin Voivodships. However, 36 people refused to participate in the study. Motives: "lack of time" - 11 persons , "I don't teach ecology in my classes" - a narrow understanding of sustainable development education (note by I.W.) - 8 persons, "due to the disability of my students I do not implement the content in this field" 4 persons, "unfortunately I will not complete this questionnaire, because I do not agree with the idea of sustainable development for me it is another type of camouflaged totalitarianism, and I don't have time to develop this thought, let alone in the survey" 1 teacher. We can hope that despite this negative attitude towards the idea of sustainable development, the teacher implements the contents of the core curriculum corresponding to education for sustainable development and shapes the system of values necessary for sustainable development in his pupils. The remaining 12 persons did not justify their refusal to participate in the research. In the end, the questionnaires filled in by 164 teachers working with students with moderate and severe intellectual disabilities and multiple disabilities were analysed. Due to the deliberate selection of the research sample and its size, the results of the survey should be treated as approximate and the generalisations made should apply only to the group of teachers participating in the survey.

\section{Interpretation of the implementation of education for sustainable development in special education}

Indications concerning education for sustainable development can be found in international reports, binding legal acts, strategic documents, organizational and program documents of the examined special schools. For example, the Report of the International Education Commission, chaired by Jacques Delors (1996), points to the importance of education not only for economic growth, the creation of a better world, sustainable human development based on the ability to control and adapt to change ${ }^{22}$. Recommendations for edu-

${ }^{22}$ Edukacja - jest w niej..., op. cit., pp. 67-70. 
cation for sustainable development can also be found in: the Millennium Development Goals formulated at the UN Millennium Summit in 200023, the Strategy for Education for Sustainable Development of the European Economic Commission24, UNESCO Global Action Programme on Education for Sustainable Development ${ }^{25}$. In Poland, the basis for the implementation of the model of sustainable development and thus education for sustainable development is the Constitution of the Republic of Poland. Article 5 of the Constitution reads as follows:

"The Republic The Republic of Poland shall safeguard the independence and integrity of its territory and ensure the freedoms and rights of persons and citizens, the security of the citizens, safeguard the national heritage and shall ensure the protection of the natural environment pursuant to the principles of sustainable development ${ }^{26}$. Whereas Article 1 point 15 of the Act of 14 December 2016, Educational Law assumes that the tasks of the education system include, inter alia, "The dissemination of knowledge about the principles of sustainable development among children and youth and shaping attitudes conducive to its implementation on a local, national and global scale"27.

The objectives of ESD are also reflected in the core curriculum. Given the place of employment of special educators participating in the survey, only the core curriculum for the education of students with moderate and severe intellectual disabilities was analysed in this study. The results are shown in table no. 1.

${ }^{23}$ Milenijne Cele Rozwoju, <http://www.unic.un.org.pl/cele.php> [30.04.2019].

24 Strategy for Education for Sustainable Development of the European Economic Commission, <www.unece.org/fileadmin/DAM/env/esd/strategytext/strategyinPo lish.pdf> [30.04.2019].

25 Global Action Programme on Education for Sustainable Development, <https://en. unesco.org/gap> [30.04.2019].

26 Constitution of the Republic of Poland, Article 5, Journal of Laws of 1997, No. 78, item 483.

27 Act of 14 December 2016 Educational law, Article 1, point 15, Journal of Laws of 2017 item 59. 
Table 1. ESD objectives and the core curriculum for general education for students with moderate or severe intellectual disabilities

\begin{tabular}{|c|c|c|c|}
\hline No. & \multicolumn{2}{|c|}{ Types of documents } & References to ESD \\
\hline \multirow[t]{3}{*}{1.} & \multirow[t]{3}{*}{$\begin{array}{l}\text { The core curriculum of ge- } \\
\text { neral education for stu- } \\
\text { dents with moderate or se- } \\
\text { vere intellectual disabilities } \\
\text { (primary school, schools } \\
\text { providing preparation for } \\
\text { work - SPDP) } 28 \text { and the } \\
\text { core curriculum of general } \\
\text { education for students with } \\
\text { moderate or significant } \\
\text { intellectual disabilities in } \\
\text { primary and lower second- } \\
\text { ary schools (lower second- } \\
\text { ary school) }\end{array}$} & $\begin{array}{l}\text { Primary } \\
\text { school }\end{array}$ & $\begin{array}{l}\text { - learning objectives - general requirements (especially } \\
\text { objectives } 1,4,5) ; \\
\text { - school tasks }(1,4 \mathrm{~b}, 4 \mathrm{l}, 4 \mathrm{~m}, 4 \mathrm{n}, 4 \mathrm{~s}, 4 \mathrm{t}, 4 \mathrm{u}, 4 \mathrm{x}, 4 \mathrm{y}, 4 \mathrm{z}, 4 \mathrm{aa}) \text {; } \\
\text { - purpose of classes in the scope of personal and social } \\
\text { functioning: "comprehensive pupil development and } \\
\text { preparation for social roles in order to enable them to } \\
\text { function in the best possible way in the future and to } \\
\text { integrate into the environment as much as possible"; } \\
\text { - Physical education objectives (mainly objectives } 4-10) ; \\
\text { - teaching content enabling students to: get to know } \\
\text { themselves better, their own needs, know and under- } \\
\text { stand the relationship with the surrounding world, } \\
\text { processes taking place in this world, take pro-health } \\
\text { and pro-ecological actions, build proper consumer be- } \\
\text { haviours, rational use of natural resources, culture, } \\
\text { technology and information technology, taking care of } \\
\text { their own and others' safety, respecting the rights and } \\
\text { dignity of others. }\end{array}$ \\
\hline & & $\begin{array}{l}\text { Lower } \\
\text { secondary } \\
\text { school }\end{array}$ & $\begin{array}{l}\text { - Learning objectives, school tasks (3-17), educational } \\
\text { content (including } 1,2,10,12,13,14) .\end{array}$ \\
\hline & & SPDP & $\begin{array}{l}\text { - learning objectives - general requirements (especially } \\
\text { objectives } 2-10,18,19,21) \text {; } \\
\text { - school tasks }(1-4,8,9,23-25,27-31,35) \text {; } \\
\text { - the objectives and content of the educational activities; } \\
\text { the priority of working with pupils is "to enhance their } \\
\text { personal, social and communication competences, to } \\
\text { experience and understand adult life situations }(\ldots) \text { of } \\
\text { maximum integration with other members of the local } \\
\text { community", to enable them to get to know themselves, } \\
\text { respect human dignity, diversity, care for cultural her- } \\
\text { itage, natural resources, etc. }\end{array}$ \\
\hline
\end{tabular}

28 Regulation of the Minister of National Education of 14 February 2017 on the core curriculum of pre-school education and the core curriculum of general education for primary schools, including for students with moderate or severe intellectual disabilities, general education for first-degree vocational schools, general education for special schools preparing for work and general education for post-secondary schools, Journal of Laws of 2017, item 356.

${ }^{29}$ Regulation of the Minister of National Education of 27 August 2012 on the core curriculum of pre-school education and education in particular types of schools, Journal of Laws of 2012, item 977. 
As can be seen from the above table, the core curriculum sets the directions for the implementation of ESD in special education institutions. The indications contained therein are general and every teacher can implement them in accordance with the needs and capabilities of his or her pupils. The question arises whether they are reflected in the internal documents of the examined institutions concerning the organisation of work, undertaken preventive and educational actions, etc. In order to answer this question, the documentation of 10 special education institutions in the Lublin and Silesian Voivodships was analysed. As a result, it can be stated that the content related to ESD is included in the following documents of the schools surveyed: the statute, the concept of school work, the educational and preventive programme, descriptions of EU projects, innovations and special interest groups. The first of these documents focuses mainly on the social aspects of the Framework, while the content of documents concerning educational projects, innovations or special interest groups refers to specific objectives of ESD and has a narrower scope (e.g. ecology, health care, etc.).

Implementation of education for sustainable development in special schools in the opinion of the surveyed teachers

All respondents confirmed the implementation of ESD in the schools in which they work. According to their declarations, this results from: the core curriculum (141 indications), implementation of educational and preventive programmes (56 indications), management's expectations (32 indications), objectives of implemented innovations and teachers' own programmes (29 indications) and EU projects (15 indications) ${ }^{30}$. According to the teachers surveyed, apart from the activities related to the implementation of the core curriculum, the issues related to ESD are addressed during:

- extra-curricular activities - special interest groups, activities organized within educational projects and pedagogical innovations, activities of associations (e.g. healthy eating, physical

${ }^{30}$ Respondents could provide more than one answer to each of the questions concerning the implementation of ESD in their place of employment. 
activity in water, nature conservation, learning about other cultures, etc.) - 113 indications);

- intra-school, local and national charity and other actions "developing empathy, respect for the dignity of others, their differences and sensitivity to the needs arising from them", organized on the occasion of e. g. "19 days against violence and harm to children and youth", "The International Day of Tolerance", "The International Day of Aid to the Needy", etc. (108 indications);

- competitions and thematic excursions "thanks to which children discover the beauty of the region and the country, actions taken to protect the environment and preserve cultural heritage" (36 indications);

- theatrical classes, during which students prepare performances showing civilization, social and cultural problems, "learn to look at the world and these problems through the eyes of other people" (3 indications);

- activities of the school self-government (2 indications),

- activities of the School Volunteer Club (1 indication).

According to the respondents, teachers employed in special schools cooperate not only within the school, but also establish contacts with local, national and foreign entities in order to implement ESD. However, these activities usually concern specific thematic areas (e.g. cultural diversity, heritage conservation, ecology, health prevention, etc.).

\section{The effects of implementing education for sustainable development in the opinions of special educators}

When describing the results of their activities, teachers focused mainly on the changes visible in the knowledge, behaviours and attitudes of students. Some limited themselves to general statements: increase of sensitivity in the field of nature protection ( 2 indications); active participation in charity actions (1 indication); 
"awareness that the world belongs to me - co-responsibility, respect for property, nature (1 indication).

Others referred to specific changes perceived in the everyday functioning of pupils:

- increasing responsibility, taking care of one's environment (the classroom, school, the area around the school) - organizing, segregating waste at school (40 indications) and at home (27 indications), saving water and energy consumption (52 indications);

- organisation and active participation in the collection of secondary materials (37 recommendations);

- improvement of social functioning (35 indications), including: compliance with the rules prevailing in the team - mutual respect, empathy (19 indications), improvement of mutual relations (11 indications), thinking about others, willingness to help the weaker (4 indications), tolerance for differences in tastes, expectations, views (1 indication);

- increase in health care, e. g. change in eating habits, consumption of water and juices instead of carbonated beverages, physical activity, taking care of oneself and others' safety (20 indications);

- active participation in charity events (e.g. raising funds, bottle tops, pet food, etc.), encouraging parents to participate (11 guidelines);

- willingness to participate in various activities, ceremonies, events, greater motivation and perseverance during the implementation of joint activities for the benefit of the natural environment, local environment (11 guidelines);

- perceiving various problems in the environment and the willingness to solve them ( 2 indications);

- saving materials, e. g. paper (1 indication);

- willingness to acquire new knowledge in this field (1 indication);

- "they squash the bottles before they throw them into the waste bin, collect waste paper, collect bottle tops. Children know 
where the old batteries collection point is in the school. With every month they are more knowledgeable about sustainable development - as can be seen from what they say in early school education classes (indication).

Only two people did not answer that question. The analysis of the responses of special educa1 tors concerning the manifestations of internalisation of sustainable development by their students showed that the respondents referred mainly to environmental (natural) aspects of sustainable development and less frequently to social and economic aspects. They also omitted cultural aspect.

\section{Summary and conclusions}

According to the declarations of the surveyed teachers, special schools implement the assumptions of ESD (implementation of the core curriculum and extracurricular activities related to EU projects, innovations or teachers' own programs). Special educators cooperate in this field within the school and take part in external initiatives. They encourage students not only to participate in classes and actions, but also to submit their own proposals for actions. They support students in transferring good habits to their families. Thus, they shape their initiative and ability to cooperate in planning and implementing team projects aimed at improving the quality of their own lives, their contemporaries and future societies.

It is worth remembering, however, that respondents build pupils' competences in the field of sustainable development in a narrow way. They usually focus on one environmental aspect of the model. They are less likely to relate to social and economic issues. It does not follow from their statements that they try to analyse the links between the natural environment and socio-cultural and economic issues with their pupils. Such analyses relate only to the relationship between the environment and economy (on a macro and micro scale) - pollution, waste and the possibility of introducing changes. Therefore, it seems justified to enable special educators to 
exchange experiences, disseminate information about good practices, undertake cooperation within the framework of implemented projects, innovations of inter-school range. It is important to support their activities through parallel education of a lifelong nature.

\section{Bibliography}

[1] Bałachowicz J., Idea zrównoważonego rozwoju w edukacji dziecka, „Prima Educatione" 2017, Vol. 1, pp. 21-38.

[2] Banaszak B., The Constitution of the Republic of Poland, C.H. Beck, Warszawa 2012.

[3] Batorczak A., Edukacja dla Zrównoważonego Rozwoju w Polsce i w Wielkiej Brytanii. Doctoral dissertation, Warsaw University, Warszawa 2013, pp. 113-184, <https:// depotuw.ceon.pl/bitstream/handle/item/457/Praca\%20doktorska.pdf?sequ ence $=1>[30.04 .2019]$.

[4] Bukowski Z., Zrównoważony rozwój w systemie prawa, Towarzystwo Naukowe Organizacji i Kierownictwa, Toruń 2009.

[5] Education - there is a treasure hidden in it. Report for UNESCO by the International Commission for Education chaired by Jacques Delors, Association of Polish Educators of the UNESCO Publishing House, Warszawa 1998.

[6] Expert opinion on education for sustainable development in Poland. Final report. Developed by a team of ITTI consultants, commissioned by the Ministry of the Environment. Poznań 2012, <https://www.gov.pl/web/srodowisko/badaniadotyczace-edukacji-dla-zrownowazonego-rozwoju > [30.04.2019].

[7] Gajuś-Lankamer E., Wójcik A.M., Analiza ciagłości edukacji dla zrównoważonego rozwoju w aspekcie środowiskowym na różnych poziomach kształcenia ogólnego w Polsce, „Problemy Ekologii” 2009, Vol. 13, No. 5, pp. 249-250.

[8] Global Action Programme on Education for Sustainable Development, <https://en. unesco.org/gap> [30.04.2019].

[9] Jastrzębska E.M. et al., Jak uczyć o społecznej odpowiedzialności i zrównoważonym rozwoju. Przewodnik dla nauczycieli, Forum Odpowiedzialnego Rozwoju, Warszawa 2011.

[10] Constitution of the Republic of Poland, Journal of Laws of 1997, No. 78, item 483.

[11] Kostecka J., Dekada edukacji dla zrównoważonego rozwoju - wizja, cel, strategia, „Problemy Ekorozwoju - Problems of Sustainable Development" 2009, Vol. 4, No. 2, pp. 101-106.

[12] Kozak Z., O pojęciach rozwoju zrównoważonego i ekorozwoju, [in:] Ochrona środowiska w filozofii i teologii, ed. J.M. Dołęga, J.W. Czartoszewski, Wydawnictwo ATK, Warszawa 1999, pp. 257-259. 
[13] Lewandowska E., Zrównoważony rozwój i edukacja dla zrównoważonego rozwoju. Konceptualizacja idei, [in:] Edukacja dla zrównoważonego rozwoju w perspektywie społeczeństwa wiedzy, ed. A. Korwin-Szymanowska, E. Lewandowska, A. Witkowska-Tomaszewska, Wydawnictwo Akademii Pedagogiki Specjalnej, Warszawa 2016, pp. 39-72.

[14] Milenijne Cele Rozwoju, <http://www.unic.un.org.pl/cele.php> [30.04.2019].

[15] National Strategy for Ecological Education, Ministry of the Environment, Warszawa 2001.

[16] Our Common Future. Report of the World Commission on Environment and Development, PWN, Warszawa 1991.

[17] Ogrodnik B., Filozoficzne podstawy edukacji na rzecz zrównoważonego rozwoju, [in:] Filozofia, psychologia i ekologia w edukacji dla zrównoważonego rozwoju, ed. B. Ogrodnik, R. Kulik, P. Skubała, Śląski Ogród Botaniczny, Mikołów 2010, pp. 9-47.

[18] Olejarczyk E., Zasada zrównoważonego rozwoju w systemie prawa polskiego wybrane zagadnienia, „Przegląd Prawa Ochrony Środowiska” 2016, No. 2, pp. 119-140.

[19] Papuziński A., Edukacja ekologiczna jako instrument polityki ekologicznej, [in:] Polityka ekologiczna III Rzeczypospolitej, ed. A. Papuziński, Wydawnictwo Uczelniane AB, Bydgoszcz 2000, pp. 113-132.

[20] Pawłowski L., Rola monitoringu środowiska w realizacji zrównoważonego rozwoju, „Rocznik Ochrona Środowiska” 2011, Vol. 13, pp. 333-345.

[21] Polish UNESCO Committee, Agenda for Sustainable Development 2030, <http:/ / www.unesco.pl/662> [30.04.2019].

[22] Polish UNESCO Committee, UNESCO and the Decade of Education for Sustainable Development, <http://www.unesco.pl/edukacja/dekada-edukacji-nt-zrownowa zonego-rozwoju/unesco-a-zrownowazony-rozwoj> [30.04.2019].

[23] Regulation of the Minister of National Education of 14 February 2017 on the core curriculum of pre-school education and the core curriculum of general education for primary schools, including for students with moderate or severe intellectual disabilities, general education for first-degree vocational schools, general education for special schools preparing for work and general education for post-secondary schools, Journal of Laws of 2017, item 356.

[24] Regulation of the Minister of National Education of 27 August 2012 on the core curriculum of pre-school education and education in particular types of schools, Journal od Laws of 2012, item 977.

[25] Rydzewski P., Social Dimensions of Sustainable Development in International Public Opinion, „Problemy Ekorozwoju - Problems of Sustainable Development” 2019, Vol. 14, No. 1, pp. 53-62.

[26] Skowroński A., Zrównoważony rozwój perspektywa dalszego postępu cywilizacyjnego, „Problemy Ekorozwoju - Problems of Sustainable Development” 2006, Vol. 1, No. 2, pp. 47-57. 
[27] Sztumski W., Idea zrównoważonego rozwoju a możliwości jej urzeczywistniania, „Problemy Ekorozwoju - Problems of Sustainable Development” 2006, Vol. 1, No. 2, pp. 73-76.

[28] Śledzińska K., Kategoria odpowiedzialnego uczestnictwa jako aspekt edukacji na rzecz zrównoważonego rozwoju, [in:] Społeczna odpowiedzialność jako podstawa osiagania zrównoważonego rozwoju, ed. O. Kotowska-Wójcik, M. Luty-Michalak, Wydawnictwo Naukowe UKSW, Warszawa 2016, pp. 85-121.

[29] Terlecka M.K., Idea zrównoważonego rozwoju - o genezie, definicji, celach i zasadach stów kilka, [in:] Zrównoważony rozwój. Idea czy konieczność? Vol. 1, ed. A. Kleśta, M.K. Terlecka, Wydawnictwo ARMAGRAF, Krosno 2014, pp. 7-15.

[30] United Nations Educational, Scientific and Cultural Organization, Teaching and Learning for Sustainable Future, <http://www.unesco.org./eduacation/tlsf/> [30.04.2019].

[31] Act of 14 December 2016 Educational Law, Journal of Laws of 2017, item 59.

[32] Walosik A., Przez edukację do zrównoważonego rozwoju, Wydawnictwo Naukowe UP, Kraków 2013.

[33] <www.europarl.europa.eu/factsheets/pl/sheet/3/traktat-z-maastricht-i-traktatz-amsterdamu> [30.04.2019]. 